\title{
Musculoskeletal disorders of older adults: an integrative literature review
}

\author{
Agravos ao sistema musculoesquelético do cuidador de idosos: revisão integrativa da literatura \\ Lesiones musculosqueléticas en cuidadores de ancianos: revisión integradora de la literatura
}

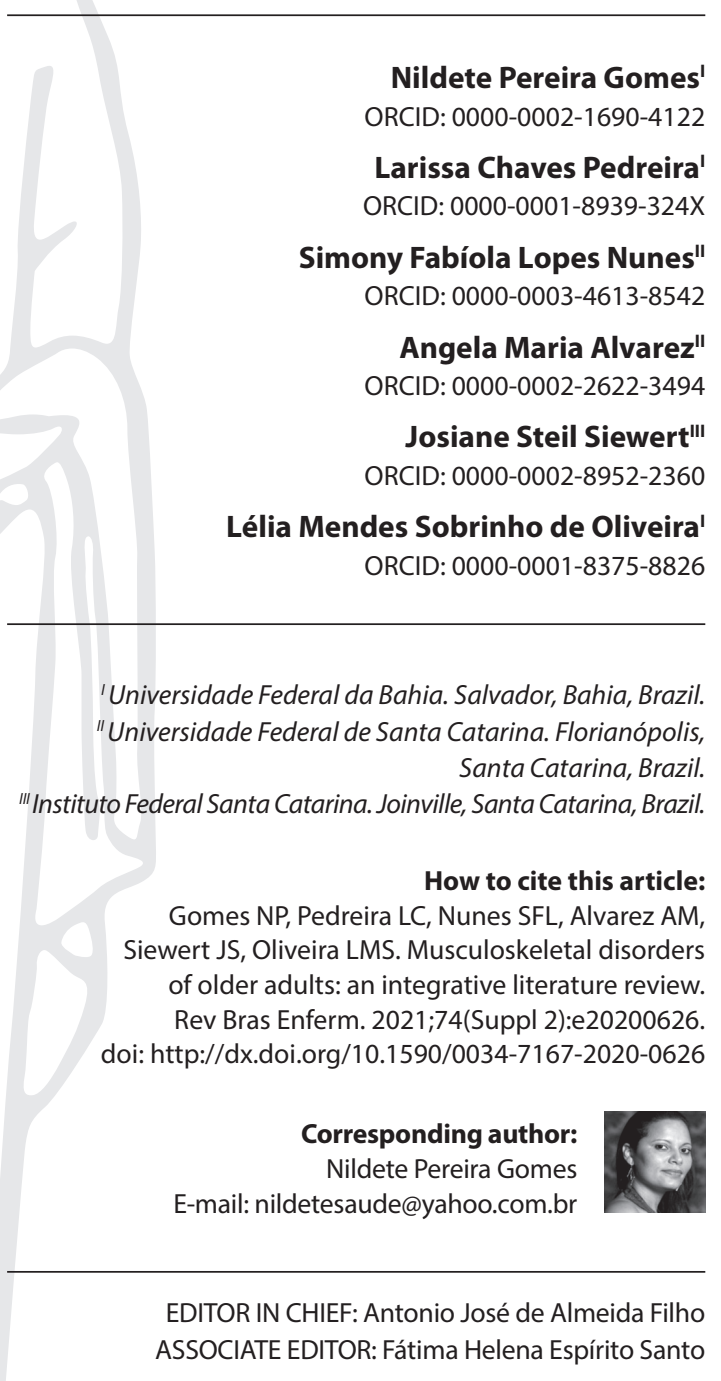

Submission: $07-28-2020$

Approval: $12-06-2020$

\begin{abstract}
Objective: to analyze in available scientific literature what problems are caused to the musculoskeletal system of caregivers of older adults in the home environment. Methods: an integrative literature review indexed in the PubMed, CINAHL, Web of Science, SCOPUS, BDENF, LILACS and SciELO databases. Results: the sample totaled 17 studies that showed three thematic categories: Care overload for caregivers' health; Caregivers' physical illness; Caregiver self-neglect. Conclusion: the evidence identified health problems for caregivers of older adults, regarding the musculoskeletal system, demonstrating the importance of considering intervention strategies that provide guidelines for self-care guidelines, in order to prevent musculoskeletal complications resulting from older adults' care activities at home. Descriptors: Caregivers; Aged; Musculoskeletal Pain; Musculoskeletal System; Activities of Daily Living.
\end{abstract}

\section{RESUMO}

Objetivo: analisar, na literatura científica disponível, quais os agravos causados ao sistema musculoesquelético do cuidador de idosos no ambiente domiciliar. Métodos: revisão integrativa da literatura, indexada nas bases de dados PubMed, CINAHL, Web of Science, SCOPUS, BDENF, LILACS e SciELO. Resultados: a amostra totalizou 17 estudos que evidenciaram três categorias temáticas: Sobrecarga do cuidado para a saúde do cuidador; Adoecimento físico do cuidador; Autonegligência do cuidador. Conclusão: as evidências identificaram agravos na saúde do cuidador de idosos no que tange ao sistema musculoesquelético, demonstrando a importância em considerar estratégias de intervenções que forneçam diretrizes para orientações de autocuidado, com intuito de prevenir as complicações osteomusculares decorrentes das atividades de cuidado ao idoso no domicílio.

Descritores: Cuidadores; Idoso; Dor Musculoesquelética; Sistema Musculoesquelético; Atividades Cotidianas.

\section{RESUMEN}

Objetivo: analizar, en la literatura científica disponible, cuáles son las lesiones causadas al sistema musculoesquelético del cuidador de ancianos en el ámbito del hogar. Métodos: revisión integrativa de la literatura, indexada en las bases de datos PubMed, CINAHL, Web of Science, SCOPUS, BDENF, LILACS y SciELO. Resultados: la muestra totalizó 17 estudios que mostraron tres categorías temáticas: Sobrecarga de cuidados para la salud del cuidador; Enfermedad física del cuidador; Auto-negligencia del cuidador. Conclusión: la evidencia identificó problemas de salud para el cuidador de ancianos con respecto al sistema musculoesquelético, demostrando la importancia de considerar estrategias de intervención que brinden pautas para pautas de autocuidado, con el fin de prevenir las complicaciones musculoesqueléticas derivadas de las actividades de atención domiciliaria de los ancianos. Descriptores: Cuidadores; Anciano; Dolor Musculoesquelético; Sistema Musculoesquelético; Actividades Cotidianas. 
Musculoskeletal disorders of older adults: an integrative literature review Gomes NP, Pedreira LC, Nunes SFL, Alvarez AM, Siewert JS, Oliveira LMS.

\section{INTRODUCTION}

With the aging of the world population, there is growing concern about the health and well-being of home caregivers of older adults with chronic diseases. In particular, both informal caregivers and older adult occupational caregivers are exposed to overload due to activities and physical effort during the provision of continuous and prolonged care ${ }^{(1)}$.

Caring for dependent older adults at home is a task that requires a lot of caregivers, going through emotional as well as physical aspects. For the purposes of this review, the term older adult caregiver was defined as anyone responsible for caring for an older adult with physical and/or mental limitations, whether paid or not ${ }^{(2)}$. Due to the dynamic nature of care over time and the manipulation of older adults without the development of skills or adequate handling devices for postural control, it is suggested that caregivers may be at greater risk of musculoskeletal injuries ${ }^{(3)}$. It is very common for the caregiver to perform care for older adults, without any type of guidance for self-care, not being sensitized to avoid injuries to their physical health.

Previous studies describe the concern with musculoskeletal health and its side effects related to the tasks of caring for older adults $^{(4-5)}$. Considering that a portion of these caregivers are already older adults taking care of another older adults, dealing with this issue is very important. The presence of symptoms and/ or diseases of the musculoskeletal system are extremely common in people between 60 and 75 years old. Added to the age factor, there is the prolonged time of care and the execution of such activities with few resources and information, which increases the risks for illness ${ }^{(6)}$. Therefore, caring for older adults, especially those dependent on care, can have significant consequences for the caregiver's well-being ${ }^{(7)}$.

The act of caring for older adults requires special attention by health professionals in order to meet health needs and support in the process of caring for caregivers.

The study is justified by the need to expand knowledge about the injuries to the musculoskeletal system that affect the caregiver of older adults, as well as serving as a subsidy for the production of new scientific knowledge, in addition to enabling public policy strategies aimed at this population. Thus, this review seeks to answer the following question: What are the injuries caused to the musculoskeletal system of the caregiver of older adults in the home environment?

This study seeks to fill the scientific gaps about caring for caregivers' physical health in order to better understand the health needs in their home environment and its consequences on the skeletal system. Thus, this review reveals itself as a current, necessary and highly relevant topic, in order to minimize the damage to the musculoskeletal system of caregivers of older adults.

\section{OBJECTIVE}

To analyze in available scientific literature what problems are caused to the musculoskeletal system of caregivers of older adults in the home environment.

\section{METHODS}

\section{Type of study}

The integrative literature review was adopted as a methodology, following the structured proposal ${ }^{(8)}$. This structure allows including qualitative, quantitative and mixed methods research, providing a framework for critical analysis of the literature that incorporates five stages, including research question formulation, conducting bibliographic research, assessing and analyzing data, and presenting the results.

\section{Research question}

The review question was formulated by adopting PICO strategy: (P) Participants: caregivers of older adults; (I) Intervention: damage to the musculoskeletal system; (C) Comparison: it was not applied; (O) Outcomes or Outcome: identification of musculoskeletal disorders caused to caregivers of older adults in the home environment.

\section{Literature search}

The databases used for bibliographic research were: Public Medline (PubMed), Cumulative Index to Nursing \& Allied Health Literature (CINAHL), Web of Science (WoS), SciVerseScopus (SCOPUS), Nursing Database (BDENF), Literature Latin American and Caribbean Health Sciences (LILACS); and the electronic library used was Scientific Electronic Library Online (SCIELO). Access to the databases occurred as follows: to access PubMed/MEDLINE, the PubMed portal was used. To access the Web of Science, CINAHL and SCOPUS, the Periodical Portal of the Coordination for the Improvement of Higher Education Personnel (CAPES - Coordenação de Aperfeiçoamento de Pessoal de Nível Superior) was used, accessed through CAFe of two Higher Education Institutions (Universidade Federal da Bahia and Universidade Federal Santa Catarina); for LILACS and BDENF, access was via Virtual Health Library (VHL); for SCIELO, the website of the electronic library was used.

The literature search was carried out between December 2019 and February 2020, using as controlled descriptors at the national level - Descriptors in Health Sciences (DeCS - Descritores em Ciências da Saúde) and internationally - the Medical Subject Headings (MeSH). The search terms used included: caregivers, older adults, musculoskeletal pain, musculoskeletal system, with the intersection of terms being mediated by the Boolean operators "AND" and "OR". In order to achieve broad search, combined access strategies were used for each database/data portal, as shown in Chart 1.

The identified articles were submitted to the inclusion criteria: original articles, describing the results related to the types of injuries to the musculoskeletal system experienced by the caregiver of older adults in the home environment written in Brazilian Portuguese, English or Spanish; and exclusion criteria: repeated or review articles or case study, dissertation, thesis, book chapter, book, manual, editorial, review, letter, comment, study protocols, conference abstracts, recommendation articles and guidelines for caution. 
Chart 1 - Search sequence performed in the databases, 2020

\begin{tabular}{|c|c|}
\hline Databases & Search sequence \\
\hline $\begin{array}{l}\text { MEDLINE/ } \\
\text { PubMed }\end{array}$ & 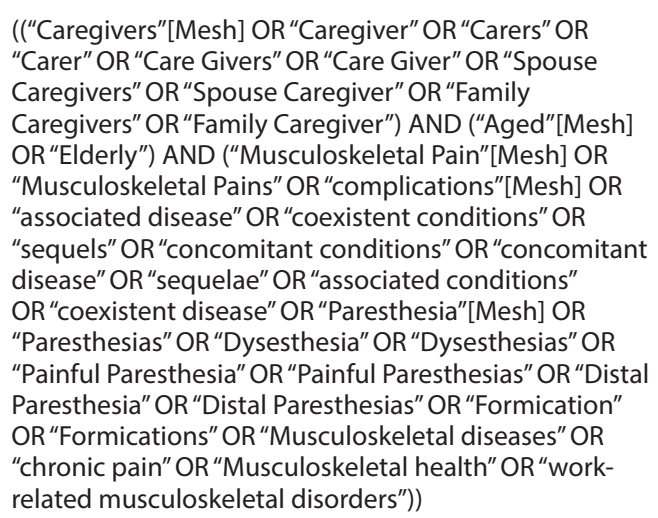 \\
\hline Scopus & 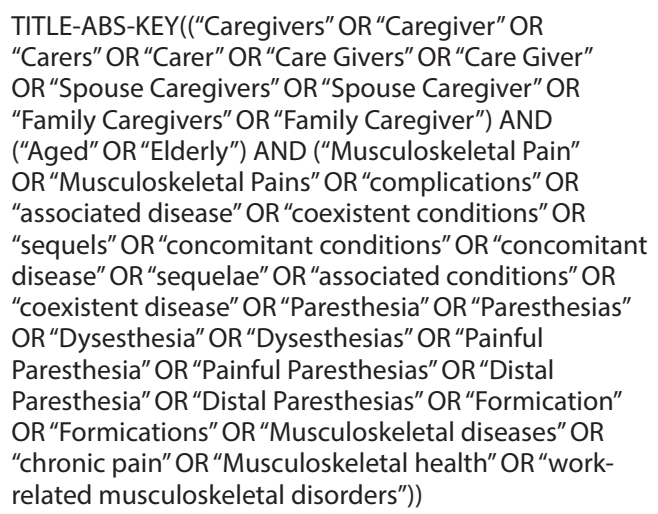 \\
\hline $\begin{array}{l}\text { Web of } \\
\text { Science }\end{array}$ & 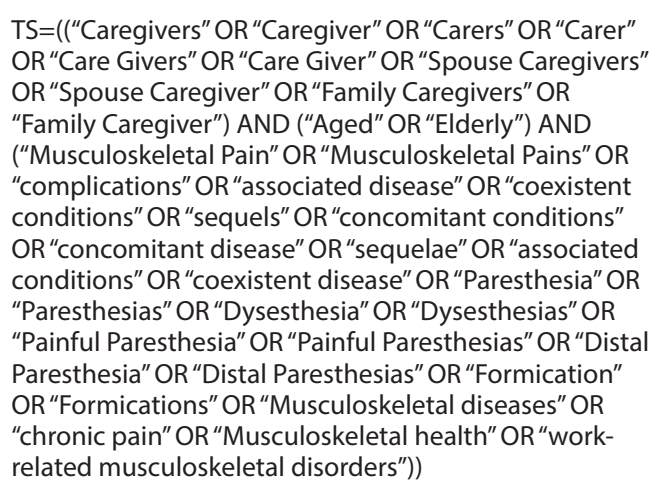 \\
\hline CINAHL & 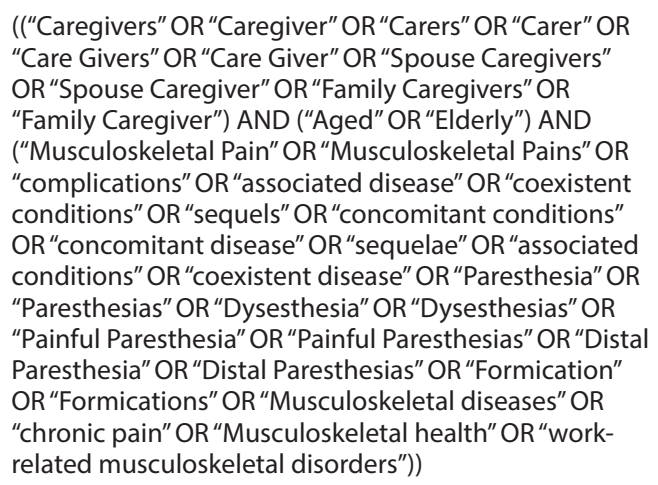 \\
\hline
\end{tabular}

To be continued
Chart 1 (concluded)

\begin{tabular}{|c|c|}
\hline Databases & Search sequence \\
\hline $\begin{array}{l}\text { BVS } \\
\text { (LILACS/ } \\
\text { BDENF) }\end{array}$ & 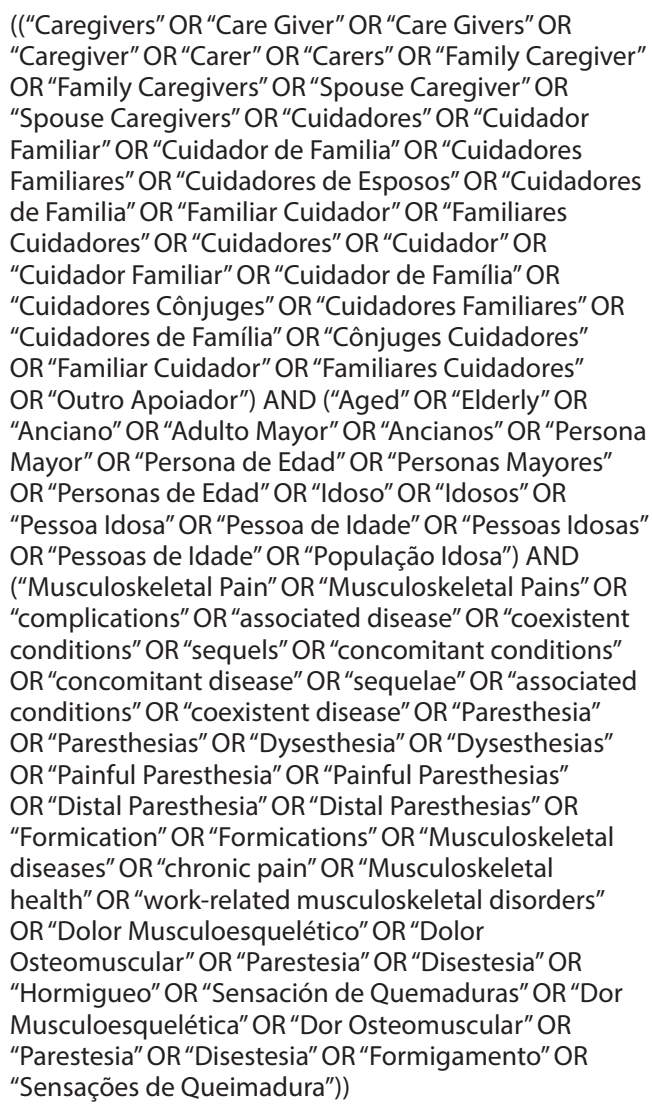 \\
\hline Scielo & 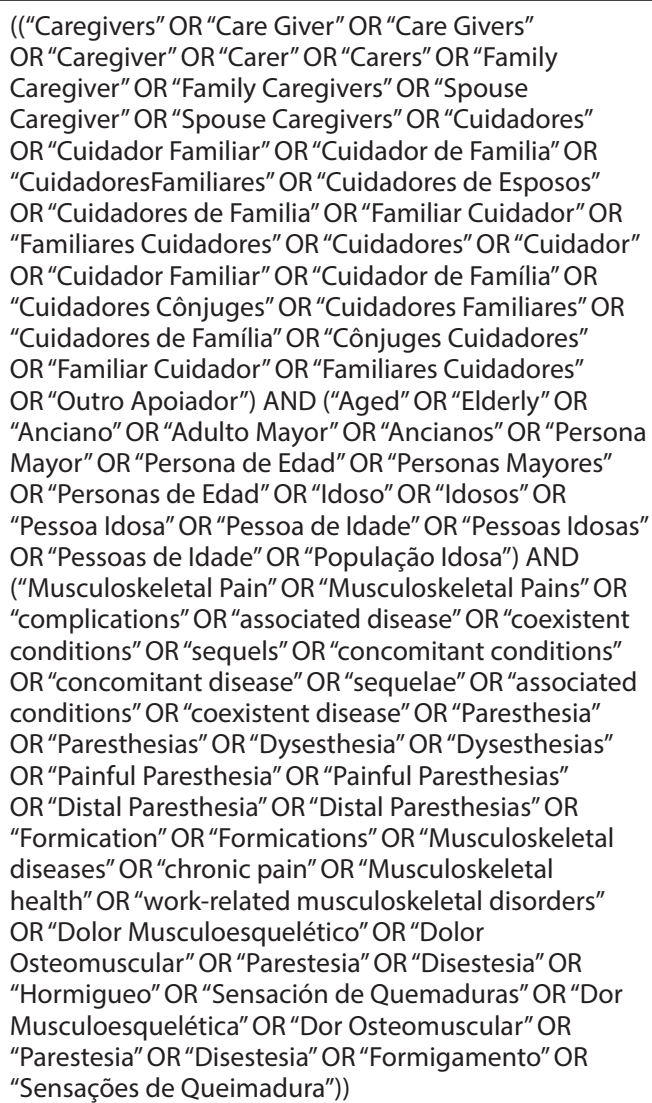 \\
\hline
\end{tabular}


For the selection of studies, cutouts with a time limit were not considered. For all selected studies, the title and abstract were read to apply the inclusion and exclusion criteria. In view of these criteria, the completed works were recovered. The search, selection and assessment steps were carried out by two researchers in parallel and independently. Any discrepancies in their findings were discussed and resolved.

All identified citations were grouped in the quote management system Mendeley. Search strategies identified 4,667 articles, with duplicates identified and deleted using the duplicate function of Mendeley, leaving 3,069 citations. After screening the titles and then the abstracts, 45 articles were selected for detailed assessment of the full text and 17 were included in this review. Figure 1 presents an overview of the study selection process.

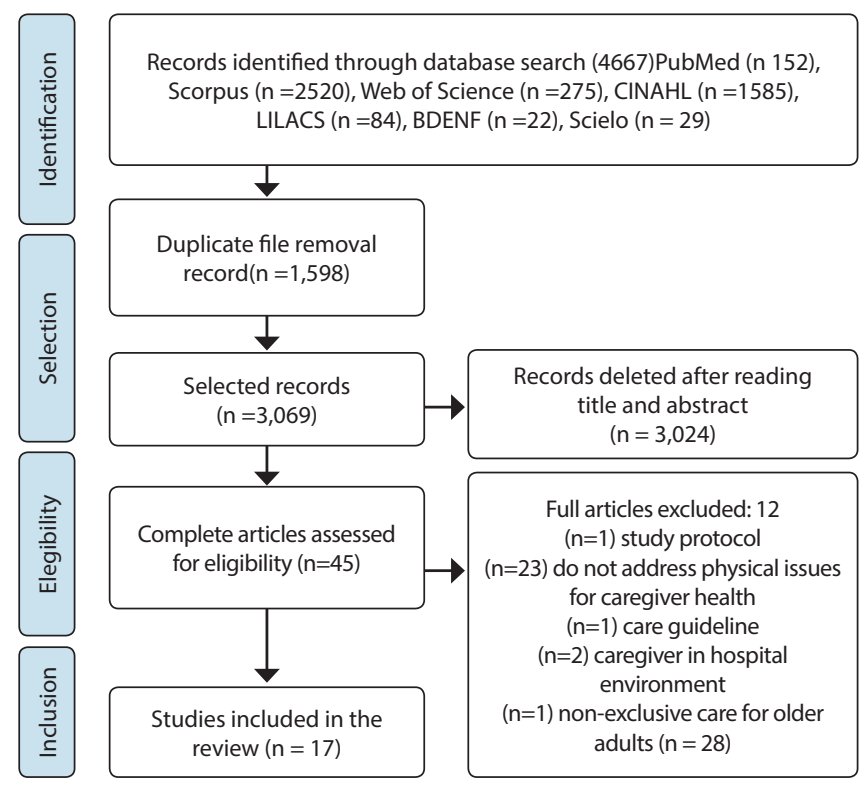

Figure 1 - Flowchart of intersections and search results, based on the Preferred Reporting Items for Systematic Review and Meta-Analysis (PRISMA), 2020

\section{Data assessment and analysis}

The data extracted from the included articles were organized in a table previously constructed for data collection, which included: article title, year of publication, country, journal name, study objectives, type of study and main results based on the question of investigation. This table was used to identify similar categories and themes to describe the results, also to learn about other relevant aspects.

The collected material was analyzed using the principles of thematic analysis for qualitative synthesis of the main themes that emerged from articles ${ }^{(9)}$. The first stage included reading and rereading each article, separating words and areas of interest. The next stage involved the exploration of the material to identify registration units and similarities of the themes, followed by the stage in which the researchers checked, reread and revised the emerging themes for the process of thematic categorization and subsequent interpretation. The categories thus appear: Care overload for caregivers' health; Caregivers' physical illness; Caregiver self-neglect. It should be noted that all themes were negatively associated with the physical health of older adults of caregivers. Later it was become fullfilled reflexiva analysis with quarrel supported in current, national and international literature.

The final stage of the integrative review, as suggested by the authors $^{(8)}$, is the presentation of results in common themes and concepts in a diagrammatic way. Thus, the results and conclusions of the enclosed studies are presented of descriptive form, synthecized in accordance with the objectives of this study in thematic way, demonstrating the logical chain of evidence.

\section{RESULTS}

\section{Characteristics of the studies}

Seventeen articles were identified that investigated the injuries to the musculoskeletal system in caregivers of older adults in the home environment. As described in Chart 2, the studies were carried out in seven countries: nine conducted in Brazil, two in the United States of America, two in Canada, one in Wales, one in Iran, one in Germany and one in Australia. The publications took place between 2005 to 2019, the year with the highest number (four) of publications identified was 2019. As for the methodology, 10 studies used quantitative methods, four qualitative and three studies used mixed method.

Chart 2 - Characteristics of the articles included in the review, regarding the title, year/country, design/participants, objective, main results and musculoskeletal disorders, 2020

\begin{tabular}{|c|c|c|c|c|c|}
\hline Title & $\begin{array}{c}\text { Year } \\
\text { Country }\end{array}$ & $\begin{array}{c}\text { Design/ } \\
\text { participants }\end{array}$ & Objective & Main results & Musculoskeletal disorders \\
\hline (4) & $\begin{array}{l}2019 \\
\text { Brazil }\end{array}$ & $\begin{array}{l}\text { Qualitative } \\
\qquad \mathrm{n}=06\end{array}$ & $\begin{array}{l}\text { To know the consequences } \\
\text { of care for the health of older } \\
\text { adult caregivers of dependent } \\
\text { family members. }\end{array}$ & $\begin{array}{l}\text { Caregivers of dependent family members reported } \\
\text { musculoskeletal pain, due to repetitive activities; } \\
\text { Somatization resulting from extreme concern for the } \\
\text { family; they do not seek health services and do not } \\
\text { perform physical activities. They reported pain, bursitis, } \\
\text { low back pain and arthrosis, with the upper limbs, knees, } \\
\text { cervical and lumbar spine the most affected regions. } \\
\text { They also reported movement limitations, such as } \\
\text { squatting and climbing/descending stairs. }\end{array}$ & $\begin{array}{l}\text { Repetitive activities; pain, } \\
\text { bursitis, low back pain and } \\
\text { arthrosis in the upper limbs, } \\
\text { knees, cervical and lumbar } \\
\text { spine; movement limitation; } \\
\text { extreme concern; they do } \\
\text { not seek health services and } \\
\text { do not perform physical } \\
\text { activities. }\end{array}$ \\
\hline (5) & $\begin{array}{c}2019 \\
\text { Australia }\end{array}$ & $\begin{array}{l}\text { Quantitative } \\
\text { n=4,056 }\end{array}$ & $\begin{array}{l}\text { To compare the biomedical } \\
\text { health profile and morbidity } \\
\text { of adult caregivers with non- } \\
\text { caregivers. }\end{array}$ & $\begin{array}{l}\text { Caregivers reported chronic health conditions, such as: } \\
\text { Anxiety }(19.2 \%) \text { and stress }(17.1 \%) \text {, musculoskeletal } \\
\text { diseases, such as arthritis }(13.7 \%) \text { and osteoporosis. They } \\
\text { also reported insufficient or no exercise ( } 26.6 \%) \text {. }\end{array}$ & $\begin{array}{l}\text { Anxiety and stress; } \\
\text { arthritis and osteoporosis; } \\
\text { insufficient or no exercise. }\end{array}$ \\
\hline
\end{tabular}




\begin{tabular}{|c|c|c|c|c|c|}
\hline Title & $\begin{array}{c}\text { Year } \\
\text { Country }\end{array}$ & $\begin{array}{l}\text { Design/ } \\
\text { participants }\end{array}$ & Objective & Main results & Musculoskeletal disorders \\
\hline (10) & $\begin{array}{c}2019 \\
\text { Germany }\end{array}$ & $\begin{array}{l}\text { Quantitative } \\
\qquad \mathrm{n}=106\end{array}$ & $\begin{array}{l}\text { To assess the exposure of the } \\
\text { family caregiver to patients' } \\
\text { critical health events and } \\
\text { examine associations with } \\
\text { general health in a palliative } \\
\text { care situation. }\end{array}$ & $\begin{array}{l}\text { Family caregivers of people in palliative care at home } \\
\text { reported more exposure to severe/severe pain and } \\
\text { discomfort (95\%), in addition to insomnia (52.8\%). }\end{array}$ & $\begin{array}{l}\text { Intense/severe pain and } \\
\text { discomfort; cannot sleep- } \\
\text { insomnia }\end{array}$ \\
\hline (11) & $\begin{array}{l}2019 \\
\text { Iran }\end{array}$ & $\begin{array}{l}\text { Qualitative } \\
\qquad \mathrm{n}=21\end{array}$ & $\begin{array}{l}\text { To explore the experiences } \\
\text { of Iranian family caregivers } \\
\text { in relation to the overload } \\
\text { of care }\end{array}$ & $\begin{array}{l}\text { Family caregivers reported physical problems resulting } \\
\text { from stress due to care provision: pain in knees, wrists } \\
\text { and stomach, general bodily pain, sleep disorders, } \\
\text { weight loss and appetite, gradual decline in physical } \\
\text { skills and fatigue. }\end{array}$ & $\begin{array}{l}\text { Physical problems resulting } \\
\text { from stress; pain in knees, } \\
\text { wrists and stomach, general } \\
\text { bodily pain; sleep disorders. } \\
\text { weight loss and appetite; } \\
\text { gradual decline in physical } \\
\text { skills and fatigue. }\end{array}$ \\
\hline (12) & $\begin{array}{l}2018 \\
\text { Brazil }\end{array}$ & $\begin{array}{l}\text { Quantitative } \\
\qquad n=41\end{array}$ & $\begin{array}{l}\text { To assess the health and } \\
\text { working conditions of } \\
\text { caregivers of frail older adults } \\
\text { using the State Reference } \\
\text { Center for Health Care of } \\
\text { Older adults }\end{array}$ & $\begin{array}{l}\text { Caregivers had a high domestic overload, } 90.2 \% \\
\text { reported being primarily responsible for the activities } \\
\text { in their home, in addition to caring for older adults. The } \\
\text { excess of activities performed caused physical overload } \\
\text { and painful symptoms for the body, compromising the } \\
\text { activity of care and the health of the caregiver. They } \\
\text { presented musculoskeletal symptoms with a greater } \\
\text { impact on the lumbar and dorsal spine. }\end{array}$ & $\begin{array}{l}\text { Domestic overload, house } \\
\text { activities, in addition to } \\
\text { care for older adults; painful } \\
\text { symptoms throughout the } \\
\text { body impacting the lumbar } \\
\text { and dorsal spine. }\end{array}$ \\
\hline (13) & $\begin{array}{l}2018 \\
\text { Brazil }\end{array}$ & $\begin{array}{l}\text { Quantitative } \\
\qquad \mathrm{n}=33\end{array}$ & $\begin{array}{l}\text { To assess the effectiveness } \\
\text { of two home ergonomic } \\
\text { interventions in order to } \\
\text { reduce the intensity of pain } \\
\text { and perceived stress and } \\
\text { improve the quality of life in } \\
\text { informal caregivers of chronic } \\
\text { post-stroke patients. }\end{array}$ & $\begin{array}{l}\text { The two groups of caregivers showed significant } \\
\text { differences such as: pain intensity in the neck, right } \\
\text { shoulder and right and left knees, and in the quality of } \\
\text { life in relation to physical health. There was a reduction } \\
\text { in pain intensity between the two experimental groups } \\
\text { after the intervention ( } 12 \text { weeks of training in postural } \\
\text { hygiene, kinesiotherapy and home adaptations). The } \\
\text { intervention reduced the perceived intensity of pain } \\
\text { in the neck, shoulders and knees of caregivers in both } \\
\text { experimental groups and increased in the control } \\
\text { group. Physical health worsened among caregivers who } \\
\text { received only the usual intervention. }\end{array}$ & $\begin{array}{l}\text { Pain in the neck, right } \\
\text { shoulder and right and left } \\
\text { knees; worse physical health. }\end{array}$ \\
\hline (6) & $\begin{array}{l}2017 \\
\text { Brazil }\end{array}$ & $\begin{array}{l}\text { Quantitative } \\
\qquad n=320\end{array}$ & $\begin{array}{l}\text { Knowing and characterizing } \\
\text { chronic pain in older adult } \\
\text { caregivers, checking the } \\
\text { cognitive performance of } \\
\text { older adults in the sample } \\
\text { and checking if there is a } \\
\text { difference in the cognitive } \\
\text { performance of older adult } \\
\text { caregivers with and without } \\
\text { chronic pain. }\end{array}$ & $\begin{array}{l}\text { Older adult caregivers with chronic pain and without } \\
\text { pain, who lived with another older adult family member } \\
\text { in the same household, reported chronic pain, with } \\
\text { intensity in the last week, which varied from absent, } \\
\text { weak, moderate, intense and unbearable, according to } \\
\text { the report of the older adults. } \\
\text { The main descriptors of pain were: uncomfortable, } \\
\text { painful and persistent, being considered a situation of } \\
\text { great discomfort and an important problem in the lives } \\
\text { of caregivers. }\end{array}$ & $\begin{array}{l}\text { Uncomfortable and } \\
\text { persistent chronic pain. }\end{array}$ \\
\hline (14) & $\begin{array}{l}2016 \\
\text { Brazil }\end{array}$ & $\begin{array}{l}\text { Quantitative } \\
\qquad n=187\end{array}$ & $\begin{array}{l}\text { To check for a difference in } \\
\text { the intensity of chronic pain } \\
\text { of frail, pre-frail and non-frail } \\
\text { caregivers. }\end{array}$ & $\begin{array}{l}\text { Caregivers presented chronic pain, being moderate } \\
\text { pain and severe pain. The main descriptors of pain } \\
\text { were: persistent, painful and uncomfortable. The most } \\
\text { affected regions of the body were: lumbar region, lower } \\
\text { limbs and dorsal region. } \\
\text { The study found no significant difference in the intensity } \\
\text { of chronic pain in older adults. }\end{array}$ & $\begin{array}{l}\text { Chronic pain, being } \\
\text { moderate and intense in } \\
\text { regions such as lumbar, } \\
\text { lower and dorsal limbs. }\end{array}$ \\
\hline (7) & $\begin{array}{l}2015 \\
\text { USA }\end{array}$ & $\begin{array}{l}\text { Qualitative } \\
\text { and } \\
\text { Quantitative } \\
\text { n=46 }\end{array}$ & $\begin{array}{l}\text { To characterize the overload } \\
\text { of care and musculoskeletal } \\
\text { discomfort associated with } \\
\text { the care of adults with chronic } \\
\text { physical disabilities and } \\
\text { describe the most physically } \\
\text { demanding care activities } \\
\text { and contributing factors } \\
\text { perceived by the informally } \\
\text { caregivers of adults with } \\
\text { physical disabilities. }\end{array}$ & $\begin{array}{l}\text { Caregivers of adults with physical disabilities reported } \\
\text { high and very high levels of physical tension associated } \\
\text { with care activities. They also reported musculoskeletal } \\
\text { discomfort in more than one part of the body. The most } \\
\text { affected body parts were: lumbar, knee, shoulder, wrist/ } \\
\text { hand, neck, hip. }\end{array}$ & $\begin{array}{l}\text { Musculoskeletal discomfort } \\
\text { in lumbar, knee, shoulder, } \\
\text { wrist/hand, neck, hip; high } \\
\text { levels of physical tension } \\
\text { associated with care } \\
\text { activities. }\end{array}$ \\
\hline (15) & $\begin{array}{l}2013 \\
\text { Brazil }\end{array}$ & $\begin{array}{l}\text { Quantitative } \\
\qquad n=40\end{array}$ & $\begin{array}{l}\text { To assess quality of life } \\
\text { and associated factors in } \\
\text { older adult caregivers with } \\
\text { impaired functional capacity. }\end{array}$ & $\begin{array}{l}\text { The study revealed a high presence of health problems } \\
\text { in caregivers, such as rheumatism associated with } \\
\text { migraine, hypertension associated with low back pain, } \\
\text { musculoskeletal problems. These health problems, } \\
\text { associated with being the main caregiver of older adults, } \\
\text { were related to the decrease in aspects of quality of life, } \\
\text { especially in the Physical Domain. }\end{array}$ & $\begin{array}{l}\text { Rheumatism, migraine, } \\
\text { hypertension, low back pain. }\end{array}$ \\
\hline
\end{tabular}




\begin{tabular}{|c|c|c|c|c|c|}
\hline Title & $\begin{array}{c}\text { Year } \\
\text { Country }\end{array}$ & $\begin{array}{l}\text { Design/ } \\
\text { participants }\end{array}$ & Objective & Main results & Musculoskeletal disorders \\
\hline (16) & $\begin{array}{l}2011 \\
\text { Brazil }\end{array}$ & $\begin{array}{l}\text { Qualitative } \\
\qquad \mathrm{n}=18\end{array}$ & $\begin{array}{l}\text { To know the experience of } \\
\text { caring for sick people in the } \\
\text { context of homes, analyzing } \\
\text { the implications of social } \\
\text { support on the physical and } \\
\text { emotional health of the family } \\
\text { caregiver. }\end{array}$ & $\begin{array}{l}\text { Family caregivers of people with chronic diseases } \\
\text { reported impaired health related to the care performed, } \\
\text { referring to back pain and migraine. }\end{array}$ & $\begin{array}{l}\text { Back pain and migraine; } \\
\text { Impairment of health } \\
\text { because of care. }\end{array}$ \\
\hline (17) & $\begin{array}{l}2011 \\
\text { Canada }\end{array}$ & $\begin{array}{l}\text { Quantitative } \\
\qquad \mathrm{n}=116\end{array}$ & $\begin{array}{l}\text { To study the associations } \\
\text { between pain, depression } \\
\text { and caregiver overload of } \\
\text { older adults. }\end{array}$ & $\begin{array}{l}\text { Caregivers in the study reported chronic pain in the last } \\
\text { six months. Most reported moderate and severe pain. }\end{array}$ & $\begin{array}{l}\text { Chronic pain from moderate } \\
\text { to severe. }\end{array}$ \\
\hline (18) & $\begin{array}{l}2010 \\
\text { Brazil }\end{array}$ & $\begin{array}{l}\text { Qualitative } \\
\text { and } \\
\text { Quantitative } \\
\qquad \mathrm{n}=50\end{array}$ & $\begin{array}{l}\text { To investigate based on } \\
\text { workers' perceptions and the } \\
\text { analysis of work activities, } \\
\text { such as relationships between } \\
\text { musculoskeletal disorders of } \\
\text { workers who care for/assist } \\
\text { older adults and aspects of } \\
\text { work organization }\end{array}$ & $\begin{array}{l}\text { Caregivers reported musculoskeletal pain in the last } \\
30 \text { days. The most affected regions were: lumbar and } \\
\text { cervical, shoulders, hip and hands. They presented work- } \\
\text { related overload, often performed tasks with inadequate } \\
\text { postures, and the weight of older adults was an aspect } \\
\text { of risk for musculoskeletal pain. }\end{array}$ & $\begin{array}{l}\text { Low back and neck pain, } \\
\text { shoulders, hip and hands. } \\
\text { Work-related overload; } \\
\text { they performed tasks with } \\
\text { inadequate postures, in } \\
\text { addition to the weight of } \\
\text { older adults. }\end{array}$ \\
\hline (19) & $\begin{array}{l}2009 \\
\text { Country } \\
\text { of Wales }\end{array}$ & $\begin{array}{l}\text { Qualitative } \\
\text { and } \\
\text { Quantitative } \\
\text { n=90 }\end{array}$ & $\begin{array}{l}\text { To explore the experiences } \\
\text { of individuals with chronic } \\
\text { conditions who also care for } \\
\text { another person, usually a } \\
\text { family member. }\end{array}$ & $\begin{array}{l}\text { The results indicate that the physical health of } \\
\text { these caregivers is negatively affected by their role } \\
\text { as caregivers. These neglect their health due to } \\
\text { responsibilities and concerns of caring for others. }\end{array}$ & $\begin{array}{l}\text { Negatively affected physical } \\
\text { health; they neglect their } \\
\text { health due to responsibilities } \\
\text { and concerns of care. }\end{array}$ \\
\hline (20) & $\begin{array}{l}2009 \\
\text { Brazil }\end{array}$ & $\begin{array}{l}\text { Qualitative } \\
\qquad \mathrm{n}=05\end{array}$ & $\begin{array}{l}\text { To understand caregivers' } \\
\text { perceptions in the care of } \\
\text { clients with neurological } \\
\text { sequel, proposing strategies } \\
\text { to care for the caregiver. }\end{array}$ & $\begin{array}{l}\text { Family caregivers of people with neurological } \\
\text { impairment reported feelings of tiredness and excessive } \\
\text { concern, leading to intense physical and psychological } \\
\text { overload. }\end{array}$ & $\begin{array}{l}\text { Feelings of tiredness and } \\
\text { excessive worry, leading } \\
\text { to intense physical and } \\
\text { psychological overload. }\end{array}$ \\
\hline (21) & $\begin{array}{l}2008 \\
\text { Canada }\end{array}$ & $\begin{array}{l}\text { Quantitative } \\
\qquad \mathrm{n}=66\end{array}$ & $\begin{array}{l}\text { To examine the agreement } \\
\text { between the assessments of } \\
\text { patients and family caregivers } \\
\text { of patients'symptoms and } \\
\text { identify demographic and } \\
\text { psychosocial factors that } \\
\text { affect the levels of agreement. }\end{array}$ & $\begin{array}{l}\text { Family caregivers of cancer patients undergoing } \\
\text { palliative treatment reported lack of energy ( } 94 \%), \\
\text { drowsiness }(77 \%) \text { and pain }(77 \%) \text {. As an indirect } \\
\text { consequence to the musculoskeletal system, the article } \\
\text { points out that lack of energy and drowsiness has } \\
\text { consequences for the body. }\end{array}$ & $\begin{array}{l}\text { Lack of energy, drowsiness } \\
\text { and pain in the body. }\end{array}$ \\
\hline (22) & $\begin{array}{l}2005 \\
\text { USA }\end{array}$ & $\begin{array}{l}\text { Quantitative } \\
\qquad \mathrm{n}=97\end{array}$ & $\begin{array}{l}\text { To compare care stress, health } \\
\text { status, physical function, } \\
\text { presence and severity of } \\
\text { symptoms and self-care } \\
\text { behaviors in family caregivers } \\
\text { with depressed mood. }\end{array}$ & $\begin{array}{l}\text { Caregivers with high depressed mood reported high } \\
\text { levels of stress in care, presenting more symptoms, more } \\
\text { severity and more difficulty in physical performance, } \\
\text { when compared to caregivers with low depressed } \\
\text { mood. } \\
\text { The first presented stiffness and swelling in the joints. }\end{array}$ & $\begin{array}{l}\text { Stress in care; stiffness } \\
\text { and swelling in the joints; } \\
\text { more difficulty in physical } \\
\text { performance. }\end{array}$ \\
\hline
\end{tabular}

Based on the thematic analysis of the 17 selected articles, three themes emerged representing the main musculoskeletal disorders in older adult caregivers in the home environment: Care overload for caregivers' health; Caregivers' physical illness; Caregiver self-neglect. They will be discussed below.

\section{DISCUSSION}

\section{Care overload for caregivers' health}

Of the 17 studies analyzed, five $\mathrm{e}^{(4,7,12,16,18)}$ associated with excessive care activities resulting in musculoskeletal disorders in caregivers. The overload of activities is characterized by the responsibility of caregivers to assume domestic tasks ${ }^{(12)}$, perform baths and transfers from older adults ${ }^{(6,12)}$ and assist in the displacement of older adults ${ }^{(12)}$.

Studies have emphasized that care activities are a risk factor for musculoskeletal health in caregivers, and are related to care recipients' physical condition (such as weight and degree of dependence), as well as caregivers' physical conditions, mainly previous health problems, physical overload and, sometimes, inadequate posture when carrying out the activities.

No studies were found to assess postural changes in caregivers (such as scoliosis or hyperkyphosis); however, two studies ${ }^{(7,16)}$ associated the musculoskeletal injury with postural disorders of caregivers during the performance of care tasks that required muscle strength associated with body balance.

Among the publications, three ${ }^{(7,12,16)}$ addressed that the feeling of responsibility for long-term care activities can lead to high levels of tension and physical suffering, musculoskeletal impairment of caregivers, affecting work, care and other activities.

The investigation showed that the majority were informal, family, female and older caregivers, around 61 years old. Studies ${ }^{(23-25)}$ already point to this reality, and it is very common for women to assume the role of informal caregivers, with an average age above 49 years old. It is noticed, then, that, in the current context, there are people approaching old age and others already elderly caring for other older adults, and these caregivers, due to the aging process, have more negative repercussions for their physical health. 
Excessive care activities of family caregivers of older adults with chronic diseases are the main source of disabilities at home, being a potential risk to their well-being, quality of life and musculoskeletal health. Similar findings were found in studies ${ }^{(3,24)}$ with family-older adult caregivers dyads, showing that the physical health of caregivers is influenced, since the beginning of care, by the interaction between older adults' symptoms and problems and pre-existing comorbidities of caregivers.

A study ${ }^{(26)}$ corroborates that the accumulation of tasks can impact the health of caregivers, as they experience an overload of daily activities that implies a higher risk of physical and psychological morbidity. Caregivers overload is an indicator of negative impact that can affect physical, psychological, emotional and financial status, in addition to causing mental health outcomes ${ }^{(27)}$.

Studies highlight that, in addition to elements associated with previous health problems and physical overload, caregivers handle older adults with inadequate postures, contributing to the emergence of discomfort and musculoskeletal pain. For lacking basic guidance on how to perform care and correct postures, caregivers are exposed to ergonomic risks that can negatively impact their health ${ }^{(28)}$.

In Brazil, caregivers can, through caregivers Practical Guide ${ }^{(2)}$, find guidance on transferring patients and providing other care for bedridden or physically disabled people. However, health professionals are responsible for the biomechanical and ergonomic assessment of these tasks, keeping these caregivers informed and prepared to perform their activities safely, reducing the risk of damage to health.

The results showed that long-term responsibility in carrying out care activities causes high levels of physical and psychological tension, impairing the physical health of caregivers, affecting work, care and other life activities ${ }^{(7,12,16)}$. Informal caregivers, especially family members, experience physical, mental and emotional exhaustion, especially when they are solely responsible for longterm care. This exhaustion reflects musculoskeletal symptoms that cause limitations in physical functioning and are significantly associated with difficulty in performing daily activities ${ }^{(29)}$.

\section{Caregivers' physical illness}

Sixteen articles (4-6,10-22) address issues related to harms to the physical health of caregivers, highlighting the illness, the impairment, the regions of the body most affected and the main symptoms resulting from the sum of the feeling experienced by caregivers of older adults.

Among the musculoskeletal disorders most evident in caregivers of older adults due to care, the presence of pain is highlighted ${ }^{(4,6,10-11,18,21)}$ in body segments $s^{(4,7,11-14,16,18)}$, mainly in the spine, upper and lower limbs, with moderate to intense pain intensity ${ }^{(6,14,17)}$, characterized by being persistent and uncomfortable. Other authors point to the presence of chronic musculoskeletal diseases in caregivers ${ }^{(4-5,15)}$, such as arthritis, osteoarthritis, and osteoporosis.

Regarding the impairment of caregivers' physical health, studies point to factors that lead to functional limitations ${ }^{(4,6-7,10,18,22)}$, such as joint stiffness and swelling and musculoskeletal discomfort.

As for somatization, studies ${ }^{(4,11,15-16,20-21)}$ reveal physical symptoms as a response to somatization due to the constant concern of caregivers with the family. Among the aforementioned problems, the presence of migraine, stomach pain, sleep disorders, physical exhaustion, fatigue and feeling tired.

The act of caring for older adults, especially bedridden, can lead caregivers to trigger injuries to the musculoskeletal system, which compromise the physical health of those who care. A study on the health profile of older adults' caregivers showed that, among the most evident diseases, diseases of musculoskeletal origin stand out, such as low back pain, osteoarthritis, and arthritis ${ }^{(30)}$. In the studies included in this review, the most common musculoskeletal diseases were arthritis, osteoarthritis and osteoporosis, which resulted in musculoskeletal pain and discomfort in caregivers, especially in the regions of the cervical spine and upper and lower limbs. Such diseases can lead to several functional impairments, implying the quality of care provided.

An international study revealed that the majority of family caregivers presented some musculoskeletal symptom, with the regions most affected being, respectively, lumbar spine, thoracic region, shoulders and cervical spine ${ }^{(3)}$. The presence of pain in body segments tends to hinder older adult care, as well as compromising the health of caregivers. In this sense, a cross-sectional study carried out with 208 informal caregivers revealed that, after taking on the tasks of caring, the majority reported pain in the body, especially in the lumbar spine ${ }^{(25)}$.

It is important to note that the psychic condition of caregivers can also cause physical symptoms. Worry and anxiety, for instance, are situations that can reflect other symptoms, such as migraine, sleep disorders, fatigue and feelings of tiredness, as pointed out in four studies in this review. In addition, one study reports that anxiety can trigger somatic symptoms, often physically expressed, such as tremors, tachycardia, muscle tension, headache and low back pain ${ }^{(31)}$.

\section{Caregiver self-neglect}

Seven studies ${ }^{(4-5,11,13,18-19,22)}$ described the self-neglect of caregivers as an intensifier of injuries in the musculoskeletal system, as the continuous involvement with care and the prioritization of care for older adults generated stressors, which caused caregivers to forget about themselves.

Home care for older adults with advanced disease developed stressful caregivers, such as anxiety due to concerns about the health condition of older adults being cared for, commitment to a heavy routine of care and the overload of providing these. Such emotions caused physical suffering characterized by an accumulation of musculoskeletal problems and high levels of musculoskeletal pain.

Studies ${ }^{(4-5,11,19)}$ also found that caregivers sacrifice themselves for those receiving care, regardless of difficulties, neglecting their own health because of their caring responsibilities. Self-neglect occurred due to insufficient physical exercise and not seeking health services, resulting in musculoskeletal discomfort, gradual decline in health and physical skills over time, especially in older adults with chronic health conditions.

The results of this review reveal that caring for older adults for a long period can neglect their own physical needs for self-care, since the expectation of moral responsibility for the care and the concern 
with its performance lead to stress levels that, in this review, the authors related to musculoskeletal problems and musculoskeletal pain. Stress and musculoskeletal pain have a prospective association, and they can influence and reinforce each other; therefore, they should be seen as separate processes, but intertwined ${ }^{(32)}$.

A survey on the identification of nursing diagnoses in institutionalized older adults' caregivers found that more than half of them had the following diagnoses: poor recreational activity; sedentary lifestyle; ineffective health maintenance. All were related to the overload of daily tasks, such as work, household chores and care for family members, and, consequently, lacking time for self-care and leisure moments ${ }^{(33)}$, corroborating the findings of this review.

The practice of insufficient or nonexistent physical exercises associated with not looking for services to monitor your health leads to difficulties with functional capacity, compromising performance in the performance of daily care activities, as well as caregivers' own safety. In this sense, educational strategies on physical exercises or movement therapies that are effective in reducing the perceived intensity of pain in the neck, shoulders and knees of caregivers are valid, as proven in an intervention study with exercises designed to promote stretching, flexibility, endurance, and relaxation ${ }^{(13)}$.

In the case of older adult caregivers, self-neglect in old age has serious effects on health and quality of life and, associated with the lack of physical health, can harm these people to provide

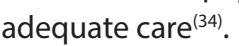

In summary of the studies in this review, mainly older adult caregivers take less care of themselves, with the emphasis on caring for the other prevailing. Such a decision can cause serious functional impairments to older adult caregivers, since the aging process results in morphophysiological changes characterized by impairment of the musculoskeletal system, such as insufficient muscle strength, instability of body balance and decline in functionality ${ }^{(35)}$. Therefore, the importance of the health professional to think and implement physical exercise programs for caregivers and health education about the comprehensive care of themselves and the person receiving care is highlighted ${ }^{(28,36)}$. Moreover, it is necessary to develop actions and public policies to meet the needs of caregivers in the face of adverse effects of home care ${ }^{(24)}$. A survey of 70 older adults caregivers that aimed to assess the effect of a nursing intervention through psychoeducation for older adults caregivers showed that there was a significant increase in the coping and adaptation capacity in the role of caring for family older adults ${ }^{(37)}$.

\section{Study limitations}

It is pointed out that, due to the methodological diversity of the studies, it was not possible to make comparisons of some outcomes. In some studies, the reflection on the repercussions of health problems in the musculoskeletal system has been little studied. Reflective analysis of these results could result in a deeper understanding of the problems experienced by caregivers of older adults in the home environment, expanding the general view of the objective of this review.

\section{Contributions to health}

It is hoped that this study may awaken in health professionals the need to guide caregivers on how to care for older adults, always focusing on self-care, especially with regard to ergonomic aspects, in order to prevent or minimize injuries in the musculoskeletal system.

\section{CONCLUSIONS}

The studies analyzed in this review revealed that activities related to the care of older adults at home can lead to impairment of the physical health of caregivers, realizing that the main injuries to the musculoskeletal system severely compromise the spine and upper and lower limbs.

The excess of activities related to care of older adults and selfneglect of caregivers lead to functional limitations, such as joint stiffness and musculoskeletal discomfort, which compromise the development of their activities, especially if caregivers are older adults. It is perceived the interrelation between the thematic categories obtained from the analysis of the articles, because the overload of activities generates health problems; in order to cope with the activities, caregivers end up neglecting their self-care. Self-neglect aggravates the health situation of caregivers, worsening the overload, as, over time, pains become part of their daily lives. It is a cycle that feeds back, substantially harming caregivers' physical and psychological health.

The results also reinforce the need for further research on the theme, aiming at self-care of caregivers and better health conditions for older adults. In addition, future studies should focus on intervention strategies that provide guidelines to guide caregivers to physical exercise practices for therapeutic purposes, as well as awareness of proper posture during care delivery, aiming to prevent or reduce musculoskeletal complications from care activities for older adults.

\section{FUNDING}

We are grateful for the support of CAPES - Financing Code 001 for the granting of a doctoral scholarship.

\section{REFERENCES}

1. Santos-Orlandi AA, Brigola AG, Ottaviani AC, Luchesi BM, Souza Érica Nestor, Moura Fernanda Gomez de et alet al. Elderly caregivers of the elderly: frailty, loneliness and depressive symptoms. Rev Bras Enferm. 2019;72(Suppl 2):88-96. https://doi.org/10.1590/0034-7167-2018-0137

2. Ministério da Saúde (BR). Secretaria de Atenção à Saúde, Secretaria de Gestão do Trabalho e da Educação na Saúde. Guia prático do cuidador [Internet]. Brasília: Ministério da Saúde. 2008 [cited 2020 Apr 12]. 64 p. Available from: https://bvsms.saude.gov.br/bvs/ publicacoes/guia_pratico_cuidador.pdf 
Musculoskeletal disorders of older adults: an integrative literature review Gomes NP, Pedreira LC, Nunes SFL, Alvarez AM, Siewert JS, Oliveira LMS.

3. Vincent-Onabajo G, Daniel H, AliyuLawan MUA, Masta MA, Modu A. Musculoskeletal symptoms among family caregivers of communitydwelling stroke survivors in Nigeria. J Caring Sci, 2018;7(2):59. https://doi.org/10.15171/jcs.2018.010

4. Gomes NP, Pedreira LC, Gomes NP, Fonseca EDOS, Reis LAD, Santos ADA. Health-related consequences of caring for dependent relatives in older adult caregivers. Rev Esc Enferm USP. 2019;53:e03446. https://doi.org/10.1590/s1980-220x2018002303446

5. Stacey AF, Gill TK, Price K, Taylor AW. Biomedical health profiles of unpaid family carers in an urban population in South Australia. PloS One. 2019;14(3). https://doi.org/10.1371/journal.pone.0208434

6. Terassi M, Rossetti ES, Gramani-Say K, Alexandre TDS, Hortense P, Pavarini SCI. Comparison of the cognitive performance of elderly caregivers with and without chronic pain. Rev Esc Enferm USP. 2017;51:e03260. https://doi.org/10.1590/s1980-220×2016023203260

7. Darragh AR, Sommerich CM, Lavender SA, Tanner KJ, Vogel K, Campo M. Musculoskeletal discomfort, physical demand, and caregiving activities in informal caregivers. J Appl Gerontol. 2015; 34(6):734-60. https://doi.org/10.1177/0733464813496464

8. Whittemore R, Knafl K. The integrative review: updated methodology. J Adv Nurs. 2005;52(5):546-53. https://doi. org/10.1111/j.1365-2648.2005.03621.x

9. Minayo, MCS. O desafio do conhecimento: pesquisa qualitativa em saúde.14ª ed. São Paulo. 2014. 416 p.

10. Galatsch M, Prigerson HG, Schnepp W, zuSayn-Wittgenstein F, Li J. Caregiver exposure to critical events and distress in home-based palliative care in Germany a cross-sectional study using the Stressful Caregiving Adult Reactions to Experiences of Dying (SCARED) scale. BMC Palliat Care, 2019; 18(1):9. https://doi.org/10.1186/s12904-019-0395-8.

11. Hassankhani H, Eghtedar S, Rahmani A, Ebrahimi H, Whitehead B. A Qualitative study on cancer care Burden: experiences of Iranian family caregivers. Holist Nurs Pract. 2019;33(1):17-26. https://doi.org/10.1097/HNP.0000000000000309

12. Vaz LCS, Santos KOB, Ferraz DD. Condições de saúde e trabalho entre cuidadores de idosos frágeis. Rev Pesqui Fisioter. 2018;8(3):319-29. https://doi.org/10.17267/2238-2704rpf.v8i3.1987

13. Moreira KLDAF, Ábalos-Medina GM, Villaverde-Gutiérrez C, Lucena NMG, Oliveira ABC, Pérez-Mármol JM. Effectiveness of two home ergonomic programs in reducing pain and enhancing quality of life in informal caregivers of post-stroke patients: A pilot randomized controlled clinical trial. Disabil Health J. 2018;11(3):471-77. https://doi.org/10.1016/j.dhjo.2018.01.003

14. Morais DD, Terassi M, Inouye K, Luchesi BM, Pavarini SCl. Chronic pain in elderly caregivers at different levels of frailty. Rev Gaúcha Enferm. 2016;37(4). https://doi.org/10.1590/1983-1447.2016.04.60700

15. Reis LA, Santos KT, Reis LA, Gomes NP. Quality of life and associated factors for caregivers of functionally impaired elderly people. Braz J Phys Ther. 2013;17(2):146-51. https://doi.org/10.1590/S1413-35552012005000078

16. Marques AKMC, Landim FLP, Collares PM, Mesquita RBD. Apoio social na experiência do familiar cuidador. Ciênc Saúde Colet. 2011;16:94555. https://doi.org/10.1590/S1413-81232011000700026

17. Jones SL, Hadjistavropoulos HD, Janzen JA, Hadjistavropoulos T. The relation of pain and caregiver burden in informal older adult caregivers. Pain Med. 2011;12(1):51-8. https://doi.org/10.1111/j.1526-4637.2010.01018.x

18. Alencar MDCB, Montrezor JB. Aspectos da organização do trabalho e os distúrbios osteomusculares: um estudo com trabalhadores em instituições de longa permanência de idosos. Rev Ter Ocup Univ São Paulo. 2010;21(1):15-22. https://doi.org/10.11606/issn.2238-6149.v21i1p15-22

19. Tommis $Y$, Robinson CA, Seddon D, Woods B, Perry J, Russell IT. Carers with chronic conditions: changes over time in their physical health. Chronic Illn. 2009;5(3):155-64. https://doi.org/10.1177/1742395309339251

20. Gomes WD, Resck ZMR. A percepção dos cuidadores domiciliares no cuidado a clientes com sequelas neurológicas. Rev Enferm UERJ [Internet]. 2009 [cited 2020 Apr 27];17(4)496-501. Available from: https://pesquisa.bvsalud.org/portal/resource/pt/bde-18012

21. McPherson CJ, Wilson KG, Lobchuk MM, Brajtman S. Family caregivers' assessment of symptoms in patients with advanced cancer: concordance with patients and factors affecting accuracy. J Pain Symptom Manage. 2008;35(1):70-82. https://doi.org/10.1016/j. jpainsymman.2007.02.038

22. Yueh-Feng Lu Y, Austrom MG. Distress responses and self-care behaviours in dementia family caregivers with high and low depressed mood. J Am Psychiatr Nurses Assoc. 2005:11(4):231-40. https://doi.org/10.1177/1078390305281422

23. Guerra HS, Almeida NAM, Souza MR, Minamisava R. A sobrecarga do cuidador domiciliar. Rev Bras Promoç Saúde. 2017;30(2):179-86 https:// doi.org/10.5020/18061230.2017.p179

24. Riffin C, Van Ness PH, lannone L, Fried T. Patient and caregiver perspectives on managing multiple health conditions. J Am Geriatr Soc. 2018;66(10):1992-7. https://doi.org/10.1111/jgs.15501

25. Mendes PN, Figueiredo MLF, Santos AMR, Fernandes MA, Fonseca RSB. Sobrecargas física, emocional e social dos cuidadores informais de idosos. Acta Paul Enferm. 2019;32(1):87-94. https://doi.org/10.1590/1982-0194201900012

26. Pereira LSM, Soares SM. Fatores que influenciam a qualidade de vida do cuidador familiar do idoso com demência. Ciênc Saúde Colet. 2015;20(12):3839-51. https://doi.org/10.1590/1413-812320152012.15632014

27. Jesus ITM, Orlandi AAS, Zazzetta MS. Burden, profile and care: caregivers of socially vulnerable elderly persons. Rev Bras Geriatr Gerontol. 2018;21(2):199-209. https://doi.org/10.1590/1981-22562018021.170155

28. Santos WP, Freitas FBD, Sousa VAG, Oliveira AMD, Santos JMMP, Gouveia BLA. Overburden on elderly caregivers who care for dependent elderly. Rev Cuid. 2019;10(2):e607. https://doi.org/10.15649/cuidarte.v10i2.607 
29. Suzuki K, Tamakoshi K, Sakakibara H. Caregiving activities closely associated with the development of low-back pain among female family caregivers. J Clin Nurs. 2016;25(15-16):2156-67. https://doi.org/10.1111/jocn.13167

30. Brandão GCG, Dias AM, Rached DS, Cartaxo RMS, Silveira MJO, Silva CM. Perfil da saúde dos cuidadores de idosos: uma revisão integrativa. RSC Online. 2017;6(1):96-113. https://doi.org/10.35572/rsc.v6i2.466

31. Quartilho MJ. O Processo de Somatização: Conceitos, Avaliação e Tratamento. Coimbra: Imprensa da Universidade de Coimbra. 2016.504 p.

32. Pihl-Thingvad J, Andersen JH, Andersen LL, Brandt LPA. Bi-directional association between stress and musculoskeletal pain: 1-year prospective cohort study with weekly registrations. Occup Environ Med[Internet]. 2018 [cited 2019 Apr 12];75(suppl 2):A260-A261. Available from: https://oem.bmj.com/content/oemed/75/Suppl_2/A260.3.full.pdf

33. Cunha JP, Cunha GH, Rodrigues AB, Amaral Gubert F, Freitas MC, Vieira NFC. Diagnósticos de enfermagem em cuidadores de idosos institucionalizados segundo Betty Neuman. Aquichan, 2019;19(1):1-12. https://doi.org/10.5294/aqui.2019.19.1.6

34. Sambasivam R, Liu J, Vaingankar JA, Ong HL, Tan ME, Fauziana R, et al. The hidden patient: chronic physical morbidity, psychological distress, and quality of life in caregivers of older adults. Psychogeriatrics. 2019;19(1):65-72. https://doi.org/10.1111/psyg.12365

35. Oliveira GG, Neves BB, Jorge LB, Neris JCD, Rauber BR, Caberlon IC, et al. Pan Am J Aging Res. 2017;4(2):54-9. https://doi. org/10.15448/2357-9641.2016.2.26181

36. Bierhals CCBK, Santos NO, Fengler FL, Raubustt KD, Forbes DA, Paskulin LMG. Needs of family caregivers in home care for older adults. Rev Latino-Am Enferm. 2017;25:e2870. https://doi.org/10.1590/1518-8345.1511.2870

37. Cuevas-Cancino JJ, Moreno-Pérez NE, Jiménez-González MJ, Padilla-Raygoza N, Pérez-Zamora I, Flores-Padilla L. Efecto de la psicoeducación en el afrontamiento y adaptación al rol de cuidador familiar del adulto mayor. Enferm Univ. 2019;16(4):390-401. https://doi.org/10.22201/ eneo.23958421e.2019.4.585 